\title{
A follow-up study examining airborne Ambrosia pollen in the Milan area in 2014 in relation to the accidental introduction of the ragweed leaf beetle Ophraella communa
}

\author{
M. Bonini $\cdot$ B. Šikoparija $\cdot$ M. Prentović $\cdot$ G. Cislaghi $\cdot$ \\ P. Colombo - C. Testoni - L. Grewling - S. T. E. Lommen • \\ H. Müller-Schärer $\cdot$ M. Smith
}

Keywords Aerobiology · Ragweed ·

Ophraella communa $\cdot$ Biocontrol agent

The North American invasive alien Ambrosia artemisiifolia L. (common or short ragweed) is considered to be an important weed in agriculture and source of highly allergenic pollen (Smith et al. 2013; Essl et al. 2015 references therein) in many parts of the world, including Europe. The oligophagous leaf beetle Ophraella communa LeSage 1986 (Coleoptera: Chrysomelidae) preferably feeds from $A$.

M. Bonini $(\bowtie) \cdot$ G. Cislaghi $~ \cdot$ P. Colombo · C. Testoni Department of Medical Prevention, Public Health, Local Health Authority of Milan 1, Parabiago, MI, Italy

e-mail: maira.bonini@aslmi1.mi.it

B. Šikoparija - M. Prentović

Laboratory for Palynology, Department of Biology and Ecology, Faculty of Sciences, University of Novi Sad,

Novi Sad, Serbia

B. Šikoparija

BioSens Institute, Novi Sad, Serbia

Ł. Grewling · M. Smith

Laboratory of Aeropalynology, Faculty of Biology, Adam

Mickiewicz University, Poznań, Poland

S. T. E. Lommen · H. Müller-Schärer

Department of Biology, University of Fribourg, Fribourg,

Switzerland artemisiifolia, and is successfully used as a biological agent to control this weed in China (Zhou et al. 2014). It can prevent plants from producing seeds and pollen when it kills them before flowering. In 2013, this beetle was found to have accidentally established in Southern Switzerland and Northern Italy, with high incidence and densities in the Milan area (MüllerSchärer et al. 2014). The map showing the presence of the beetle has now been updated for 2014 (Fig. 1). We have previously shown, using linear regression models, that the exceptionally low amounts of airborne Ambrosia pollen observed in the Milan area in 2013 could not be explained by meteorology in that year. We therefore suggested that the decrease might be related to the presence of large numbers of $O$. communa (Bonini et al. 2015).

European COST Action FA1203 (SMARTER, http://ragweed.eu) "Task Force Ophraella" is continuing to monitor the dynamics of $O$. communa and $A$. artemisiifolia in Northern Italy. Atmospheric concentrations of Ambrosia pollen are also routinely monitored in the Milan region by sites belonging to the Italian Monitoring Network in Aerobiology (R.I.M.A. ${ }^{\circledR}$ ) of the Italian Aerobiology Association (A.I.A.) using volumetric spore traps of the Hirst design (Hirst 1952) and following the standard methods of A.I.A.-R.I.M.A. ${ }^{\circledR}$ (2009). Ambrosia pollen data recorded at Legnano were used for the analysis, as this is the closest pollen-monitoring station to Malpensa airport where the meteorological data were collected (Fig. 1). 


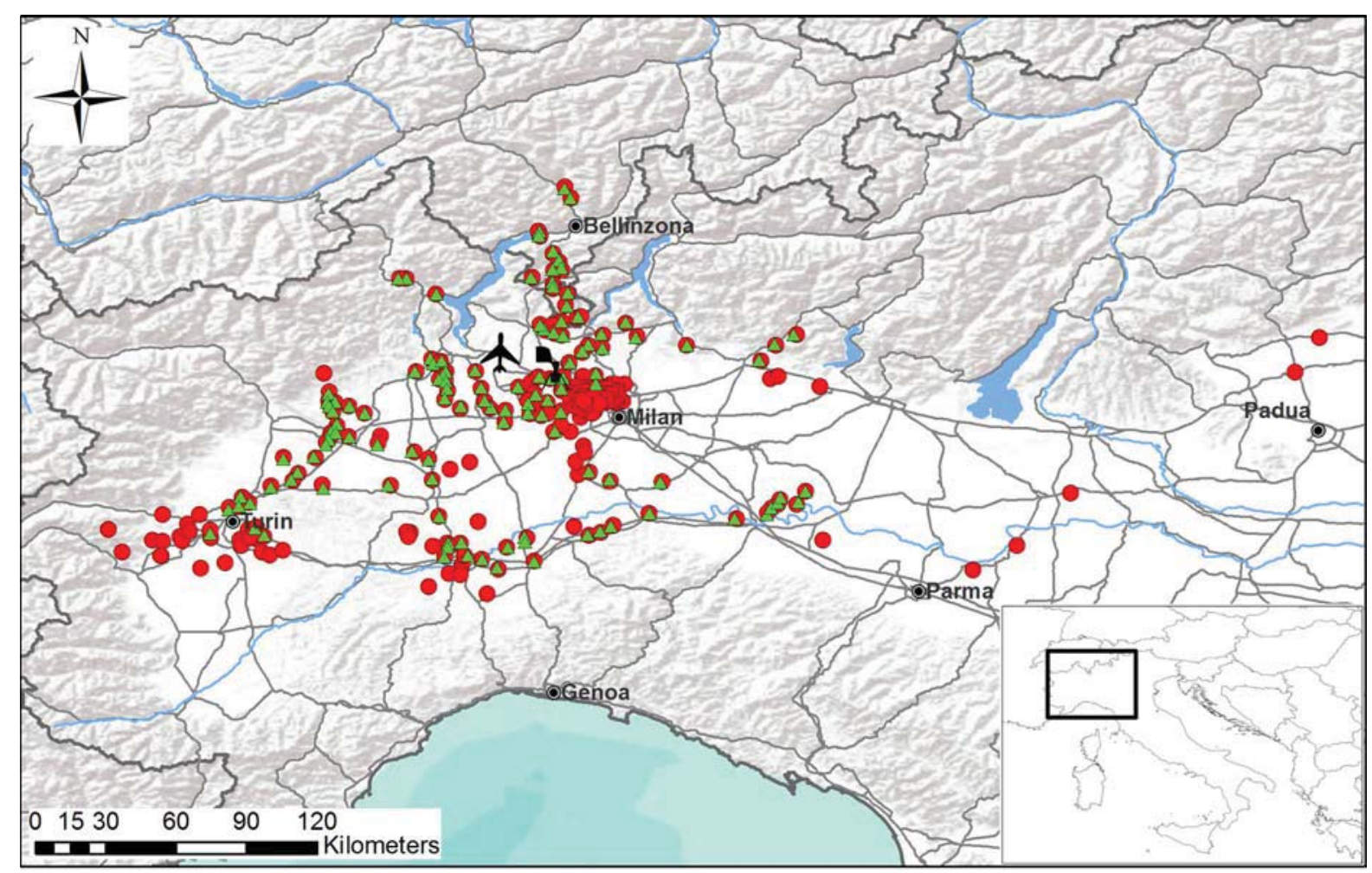

LEGEND:

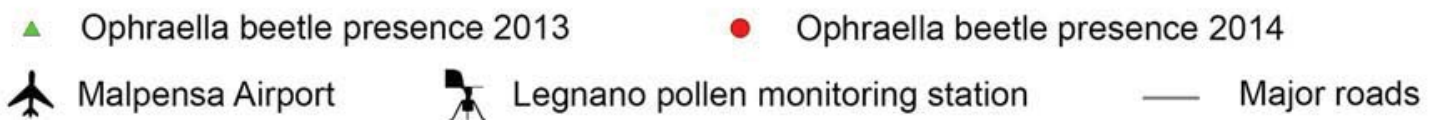

Fig. 1 The presence of the leaf beetle Ophraella communa in Southern Switzerland and Northern Italy in 2013 (Müller-Schärer et al. 2014) and in 2014. Legnano pollen-monitoring site and Malpensa airport, where the meteorological data are collected, are also shown

Minimum temperatures in March and June, humidity in June and the number of days with rainfall in September have previously been shown to significantly influence the amount of Ambrosia pollen recorded in the Milan region during August and September (Bonini et al. 2014, 2015). Conditions were generally warmer and wetter in 2014, compared to the previous year (Table 1). We therefore decided to examine airborne Ambrosia pollen levels and meteorological data recorded before and during the main flowering period of Ambrosia (August-September) in 2014, to see whether Ambrosia pollen levels were higher or lower than expected at this time. The variables of monthly meteorological data were consequently entered into one simple linear regression model and two multiple linear regression models that were constructed to predict the amount of Ambrosia
Table 1 Climate data recorded at Malpensa airport and accessed via http://www.tutiempo.net, showing 2014 values in relation to long-term mean for the period 1981-2010

\begin{tabular}{lrrc}
\hline & \multicolumn{1}{c}{2013} & \multicolumn{1}{c}{2014} & $1981-2010$ \\
\hline Mean annual $T_{\mathrm{m}}$ & 6.50 & 7.60 & 5.93 \\
Mean annual RN & 150.00 & 167.00 & 127.14 \\
$T_{\mathrm{m}}$ (March) & 0.30 & 2.20 & 0.58 \\
$T_{\mathrm{m}}$ (June) & 13.50 & 14.60 & 13.60 \\
H (June) & 60.00 & 65.60 & 67.64 \\
RN (September) & 7.00 & 12.00 & 10.50 \\
\hline
\end{tabular}

$\overline{T_{\mathrm{m}} \text { minimum temperature }\left({ }^{\circ} \mathrm{C}\right) ; \mathrm{H} \text { mean humidity }(\%) ; \mathrm{RN}}$ indicator for the occurrence of rain or drizzle

pollen recorded at Legnano (Table 2) as described in Bonini et al. (2015).

The trend towards lower amounts of airborne Ambrosia pollen recorded at Legnano, which was 
Table 2 Simple linear and standard multiple regression models for predicting the amount of airborne Ambrosia pollen recorded in August and September in Legnano

\begin{tabular}{|c|c|c|c|c|c|}
\hline Model no. & Regression equation & Adj. $R^{2}$ & $p$ & $\begin{array}{l}\text { Komolgorov- } \\
\text { Smirnov test }(p)^{1}\end{array}$ & $\begin{array}{l}\text { Koenker-Basset } \\
\text { test }(p)^{2}\end{array}$ \\
\hline 1 & $5860.751+223.308 * \mathrm{RN}($ September) & 0.308 & 0.045 & 0.200 & 0.252 \\
\hline 2 & $\begin{array}{l}6234.579-380.312 * \mathrm{Tm} \\
\quad(\text { March })-190.795 * \mathrm{RN} \\
(\text { September })\end{array}$ & 0.455 & 0.036 & 0.200 & 0.728 \\
\hline 3 & $\begin{array}{l}10751.921-79.487 * \mathrm{H} \\
\quad(\text { June })-209.352 * \mathrm{RN} \text { (September) }\end{array}$ & 0.558 & 0.016 & 0.200 & 0.685 \\
\hline
\end{tabular}

Models calibrated using data not included in model validation (Bonini et al. 2015). $T_{\mathrm{m}}$ (March) March averages of daily minimum temperatures $\left({ }^{\circ} \mathrm{C}\right) ; \mathrm{H}$ (June) June averages of daily relative humidity (\%); RN (September) number of days with precipitation (rain or drizzle) in September

${ }^{1} p>0.05$ normality of residuals distribution is not violated

${ }^{2} p>0.05$ homogeneity of residual variance (homoscedasticity) is not violated

noted in the previous study, continued (Bonini et al. 2015). The 2014 airborne pollen season was the second lowest since 2000 (Fig. 2); this was repeated at the other two stations in the Milan area-Magenta and Rho (data not shown). The three linear regression models highly overestimated the amount of airborne Ambrosia pollen recorded in August and September in 2014 (Fig. 2), particularly the simple linear regression model that only included the number of days with precipitation in September (model 1). The two standard multiple regression models that used a combination of March averages of daily minimum temperature and the number of days with precipitation in September (model 2) and June averages of daily relative humidity and the number of days with precipitation in September (model 3) were in closer agreement (in comparison with model 1), but the values were still too high (over $300 \%$ ). It is interesting to note that both models 2 and 3 predicted lower than average atmospheric concentrations of Ambrosia pollen in August and September 2014. As seen in our earlier study, the variables entered into these
Fig. 2 The amount of Ambrosia pollen recorded annually during AugustSeptember (AAP) from 2000 to 2014 at Legnano situated in the Northwest of the Province of Milan. The results of the three linear regression models used to predict the AAP in 2014 are also shown in relation to the 2000-2012 mean. Note that the mean does not include Ambrosia pollen data previously used to test the models (2009, 2010 and 2013)

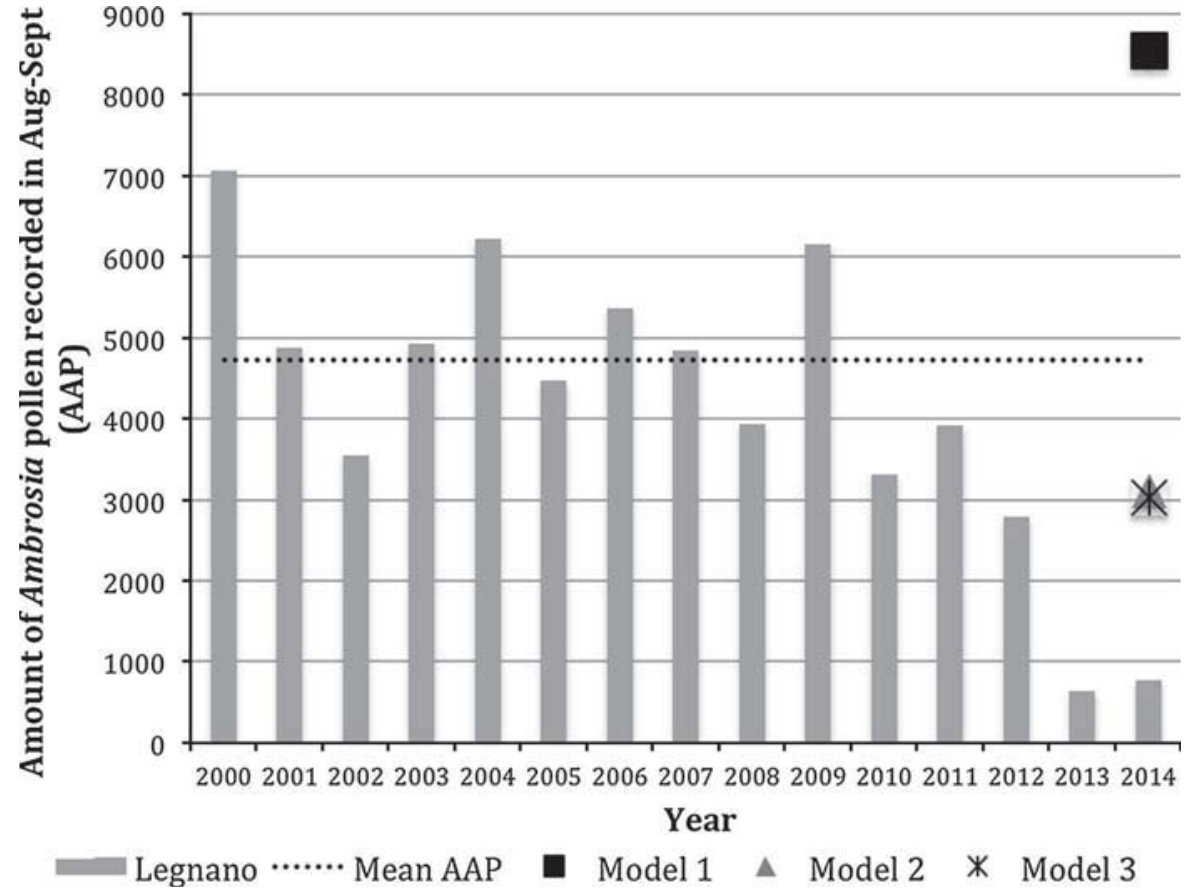


models were all negatively correlated with the amount of airborne Ambrosia pollen (Bonini et al. 2015). It therefore appears that the generally warmer and wetter conditions experienced at these times were not conducive to the production and dispersal of Ambrosia pollen, and so lower than average pollen levels were to be expected. However, this still does not explain the extremely low levels of atmospheric Ambrosia pollen recorded in 2014.

In conclusion, we provide evidence that the presence of $O$. communa may again explain the lower levels of Ambrosia pollen recorded in the Milan region in 2014. Although the densities of O. communa observed in 2014 were lower than those in 2013, we did observe that the beetle was feeding on the male flower heads. Damaged capitula had either fallen off before anthesis or contained retarded florets, thereby notably reducing the amount of available pollen ( $\mathrm{S}$. Lommen; personal observation, unpublished results). Ongoing research aims to experimentally study the effect of meteorology on Ophraella development, and on the impact of Ophraella on Ambrosia plant survival, pollen production and pollen release along an elevational gradient starting from the Milan area northwards.

Acknowledgments We acknowledge support from EU COST Action FA1203 "Sustainable management of Ambrosia artemisiifolia in Europe (SMARTER)" (http://ragweed.eu). This work was partly financed by ECOST-STSM-FA1203250415-058150 to MS. Many thanks to Olivier Broennimann (University of Lausanne, Switzerland) for helping to produce Fig. 1.

\section{References}

A.I.A.-R.I.M.A. ${ }^{\circledR}$ (2009). Manuale di gestione e qualità della rete italiana di monitoraggio in Aerobiologia. Bologna: R.I.M.A. ${ }^{\circledR}$. ISBN: 978-88-900277-1-0: 1-148.

Bonini, M., Šikoparija, B., Prentović, M., Cislaghi, G., Colombo, P., Grewling, Ł., et al. (2014). Seasonal variations in the amount airborne ragweed pollen in Milan in relation to environmental factors. Third International Ragweed Conference, Rho, Italy, April 3-4, 2014.

Bonini, M., Šikoparija, B., Prentović, M., Cislaghi, G., Colombo, P., Testoni, C., et al. (2015). Is the recent decrease in airborne Ambrosia pollen in the Milan area due to the accidental introduction of the ragweed leaf beetle Ophraella communa? Aerobiologia. doi:10.1007/s10453015-9380-8.

Essl, F., Biró, K., Brandes, D., Broennimann, O., Bullock, J. M., Chapman, D. S., et al. (2015). Biological flora of the British Isles: Ambrosia artemisiifolia. Journal of Ecology, 104(4), 1069-1098.

Hirst, J. M. (1952). An automatic volumetric spore trap. The Annals of Applied Biology, 39(2), 257-265.

Müller-Schärer, H., Lommen, S. T. E., Rossinelli, M., Bonini, M., Boriani, M., Bosio, G., \& Schaffner, U. (2014). Ophraella communa, the ragweed leaf beetle, has successfully landed in Europe: Fortunate coincidence or threat? Weed Research, 54(2), 109-119.

Smith, M., Cecchi, L., Skjoth, C. A., Karrer, G., \& Sikoparija, B. (2013). Common ragweed: A threat to environmental health in Europe. Environment International, 61, 115-126.

Zhou, Z.-S., Chen, H.-S., Zheng, X.-W., Guo, J.-Y., Guo, W., Li, M., et al. (2014). Control of the invasive weed Ambrosia artemisiifolia with Ophraella communa and Epiblema strenuana. Biocontrol Science and Technology, 24(8), 950-964. 